\title{
The Development of Active Learning Website for Learning Science
}

\author{
Mohamad Bilal Ali, Noor Dayana Abd Halim, and Nurbiha A. Shukor
}

\begin{abstract}
Active learning takes place when students are present in the classrooms' activity and actively engaged with the subject matter. Active learning via website focuses on the content delivery and active engagement with the materials. However, the emergence of web-based learning environment which is supported by the changing technology at the present, is neglecting the students' active participation in the learning processes. As a matter of fact, through the enhanced learning environment by the supported technology, students are able to play the role of an active learner. This paper examines how today's web-based learning environment can be better designed for students' active learning as in science subjects. This research proposed the implementation of learning strategies to encourage active participation among the students.
\end{abstract}

Index Terms-Active learning, passive learning, web-based leaning, learning strategies.

\section{INTRODUCTION}

The internet or web has become an important changing agent in education field at present. Numerous websites provide opportunities for students to receive information without having time and places constraint [1]. Additionally, web-based learning can fosters active learning, where students having control on their own learning processes. Thus, students have to learn to be in charge of their own learning and become actively involved in the learning processes [2].

Learning by doing is the most common learning processes as indicated by many group of educators [3]. It is also indicated by Silberman where he mentioned that "students learn best by doing" [4]. Felder and Brent also further asserted that active learning as engaging students in doing something other than listening to a lecture and taking notes to help them learn and apply course material [5].

Active learning promotes student-centered learning. According to Açıkgöz [6], in active learning particularly, student takes the responsibility of his/her learning and also given the opportunity to make decisions about various dimensions of the learning processes. As a result, the skills of problem-solving, critical thinking and learning to learn can be nurtured [6]. This is due to the fact that through active learning, students carry out most of the tasks, using their wits to generate ideas and attempt to solve the given problems and finally able to apply what they have learned [4].

Manuscript received December 9, 2012; revised April 18, 2013.

M. B. Ali and N. D. Abd Halim are with the Universiti Teknologi Malaysia (e-mail: mba@utm.my, noordayanahalim@gmail.com).

N. A. Shukor is with the Department of Educational Multimedia, Faculty of Education UTM (e-mail: fandymcl@gmail.com).

\section{BACKGROUND OF PROBLEM}

The advantages of active learning have been frequently demonstrated particularly for learning sciences [7]. Several researches have been conducted to prove that students learn best when they are engaged with course materials and actively participating in the learning processes [8]. As indicated by Clark [9], through active learning, students are engaged in activities such as conceiving, designing, creating, operating, exploring, analyzing, communicating, reflecting, or actually using new information or experiences. Despite that, studies have shown that the implementation of active learning at present is not widely spread [10].

Active learning can be enhanced and supported by technology. Currently, the integration of technology in education field will provide with the opportunities for active participation, collaboration and social interaction [11]. Active learning can also be implemented via online learning setting (web-based) [12] and it is hoped to be able to shift the passive learner towards becoming an active learner. The benefits of active learning versus passive learning are well-recognized. Cottrell [13] had listed the differences between active learning and passive learning as presented in Table I.

TABLE I: ACTIVE LEARNING VERSUS PASSIVE LEARNING

\begin{tabular}{l|l}
\hline \hline Active Learning & Passive Learning \\
\hline $\begin{array}{l}\text { Students will be looking for } \\
\text { means to get involved in } \\
\text { learning activity. }\end{array}$ & $\begin{array}{l}\text { Students will be waiting for } \\
\text { directions and information to be } \\
\text { given to them }\end{array}$ \\
$\begin{array}{l}\text { Students make conscious effort } \\
\text { to make sense of, and finding } \\
\text { meaning. Usually results in } \\
\text { deeper understanding. }\end{array}$ & $\begin{array}{l}\text { Students replicate information } \\
\text { and being ignorance. Unaware } \\
\text { of the meaning. }\end{array}$ \\
$\begin{array}{l}\text { Students involved in reflection } \\
\text { and self-assessment. }\end{array}$ & $\begin{array}{l}\text { Students do not reflect on what } \\
\text { they have learned. }\end{array}$ \\
$\begin{array}{l}\text { Students' attention span is } \\
\text { longer because their mind is } \\
\text { optimally engaged. }\end{array}$ & $\begin{array}{l}\text { Students may easily become } \\
\text { bored and tired. }\end{array}$ \\
\hline \hline
\end{tabular}

Creating active learning environments can be challenging in face-to-face meetings and it may be equally challenging in online settings [14]. Thus, understanding the pedagogical potential of technology tools for active learning is an important step in successfully implementing online learning [14]. Other than that, the motivation of the learners in learning in online settings has to be considered as well. According to Talib and friends [15], students' motivation towards learning may be influenced by several factors where active learning strategies are one of the contributing factors. This is agreed by Austin and Mescia [16] who cited that an active learning environment incorporates active learning strategies where 
students have greater chances for exploration of their meaning, attitudes and values.

The current concern is on which is the suitable learning strategies for online learning environment. For educators developing an active learning environment for online learning, there are several factors that need be considered [16]. Firstly is the course design. Next, is the context and environment in which learners will be manipulating, and finally, the instructional tools and techniques for delivery. These factors are crucial for active learning is not possible in online settings unless the interaction is intentionally planned and promoted by the educators [17].

Mantyla [18] listed several principals to design a good active learning in online environments. Activities should 1) have a definite beginning and ending; 2) have clear purposes or objectives; 3) have complete and understandable instructions; 4) have a feedback mechanism; and 5) description of the technology or tool being used in the exercise is provided. To attain to these principles, the selection of the appropriate learning strategies or approaches continues to be the main factors for developing online learning website.

In this research, we presented a web-based active learning for learning science that we called Sci-On: Active Learning Activities for Science (see Fig. 1). It incorporates the implementation of collaborative learning, inquiry-based learning, and problem-based learning as selected learning strategies for inducing active learning among the students.

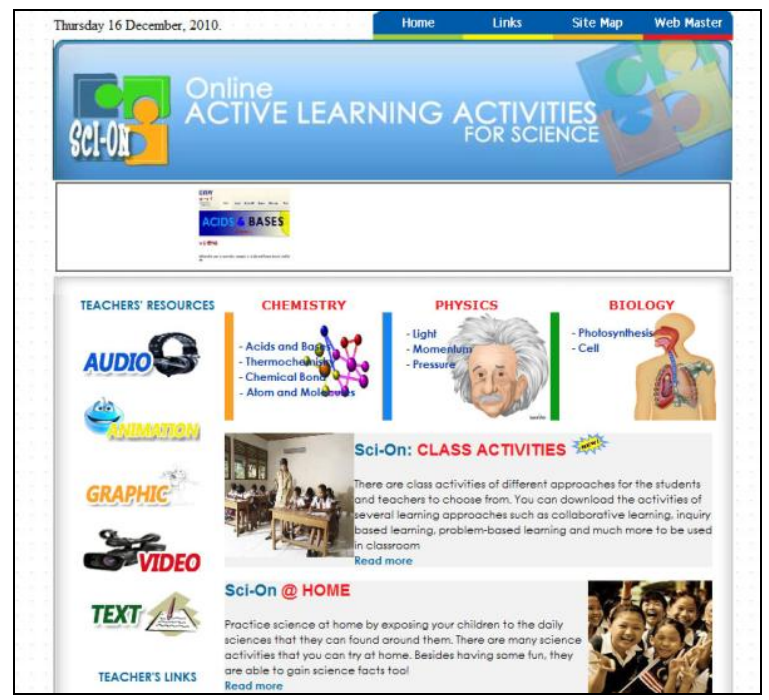

Fig. 1. The main page of Sci-On: active learning activities for science website.

\section{DeVElopment OF ACTIVE LEARNING WeBsite}

In several series of former projects by Nurbiha and colleagues [19] as well as Noor Dayana and friends [20], decisions are made to come up with an integrative online learning environment that gathers active online learning strategies; collaborative learning, inquiry-based learning and problem-based learning. Of each of the learning activities incorporated in the website, the principles by Mantyla [8] have been implemented. The implementation of the designated principles for collaborative learning (one of the applied learning strategies) is simplified in Table II.
TABLE II: SUMMARY OF THE IMPLEMENTATION OF ACTIVE LEARNING PRINCIPLES IN SCI-ON

\begin{tabular}{l|l}
\hline \multicolumn{1}{c|}{$\begin{array}{c}\text { Active Learning } \\
\text { Principles }\end{array}$} & \multicolumn{1}{c}{ Implementation } \\
\hline $\begin{array}{l}\text { Having definite } \\
\text { beginning and } \\
\text { definite ending }\end{array}$ & $\begin{array}{l}\text { Initially, students have to register their name to } \\
\text { system and ended learning of the day by } \\
\text { completing the given task. } \\
\text { Clear purpose and } \\
\text { objectives }\end{array}$ \\
$\begin{array}{l}\text { Objectives of learning are clearly stated before } \\
\text { proceed with the given task (see Fig. 2). }\end{array}$ \\
$\begin{array}{l}\text { understandable } \\
\text { instructions }\end{array}$ \\
$\begin{array}{l}\text { Feedback } \\
\text { mechanism }\end{array}$ & $\begin{array}{l}\text { possible by providing numbered instructions } \\
\text { and arranged in sequential manner (see Fig. 2). } \\
\text { Students are given a list of their group members } \\
\text { upon successful registration to the system (see }\end{array}$ \\
$\begin{array}{l}\text { Fig. 3). } \\
\text { Developer provides guidance on how to } \\
\text { technology and } \\
\text { tool being used in } \\
\text { the system }\end{array}$ & $\begin{array}{l}\text { The purpose of the discussion and the } \\
\text { outcomes of the discussion are explained } \\
\text { before-hand. }\end{array}$ \\
\hline \hline
\end{tabular}

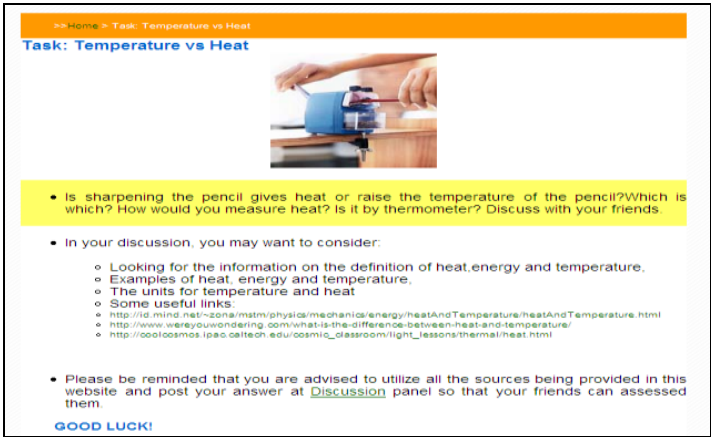

Fig. 2. The clear instructions of the task and how to carry out the task adapted from Nurbiha and colleagues [19].

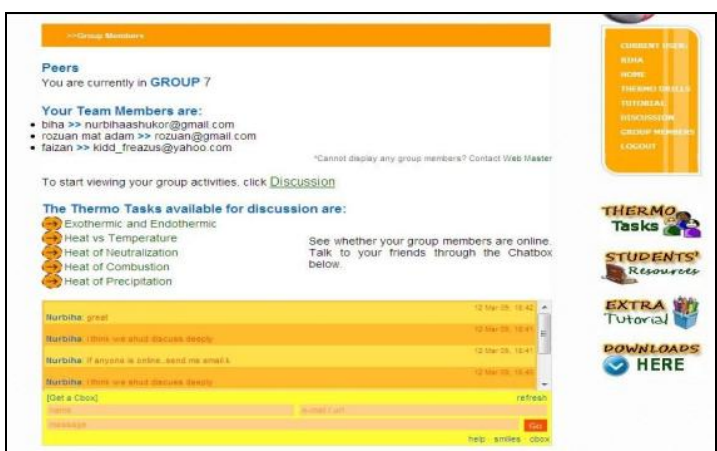

Fig. 3. One of the many form of feedbacks provided by the system adapted from Nurbiha and colleagues [19].

\section{CONCLUSION}

For successful online active learning activities, several prior steps should be reflected on. The present research has demonstrated on how the principles for designing active learning website are possible for implementation. Upon this project, the present research summons the educators or stakeholders to consider structural planning of learning strategies and approaches for developing active online learning website for students' active learning.

\section{REFERENCES}

[1] V. Chang and D. Fisher, "The validation and application of a new learning environment instrument for online learning in higher education," in Technology Rich Learning Environments; A Future Perspective, M. S. Khine and D. Fisher, Eds. Singapore: World Scientific Publishing Co. Pte. Ltd, 2003, pp. 1-2. 
[2] L. Lee, "Enhancing learners' communication skills through synchronous electronic interaction and task-based instruction," Foreign Language Annuals, vol. 35, pp. 16-23, 2002.

[3] A. Wagenaar, A. J. J. A. Scherpbier, H. P. A Boshuizen, and C. P. M. V. D. Vlueten, "The importance of active involvement in learning; A qualitative study on learning results and learning processes in different traineeships," Advances in Health Sciences Education, vol. 8, pp. 201-212, 2003.

[4] M. Silberman, Active Learning: 101 Strategies to Teach Any Subject, Boston: Allyn and Bacon, 1996.

[5] R. M. Felder and R. Brent, Effective Teaching Workshop, North Carolina State University, 1997.

[6] K. Açıkgöz, A. Öğrenme, and E. D. Yayınları, "In the effects of problem-based active learning in science education on students' academic achievement, attitude and concept learning," O. Aklnoğlu and R. Ö. Tandoğan. Eurasia Journal of Mathematics, Science \& Technology Education, vol. 3, no. 1, pp. 71-81, 2007.

[7] R. Sowell, C. Gill, R. D. Chamberlain, C. Grimm, and K. J. Goldman, "The active e-learning transformation: A case study in software development and systems software courses," JCSC 25, 5 May 2010.

[8] "Using active learning in the classroom," Instruction of FSU Handbook 2010, Chapter 8, pp. 75-102.

[9] D. R. Clark. (2000). Instructional System Design Concept Map. [Online]. http://www.nwlink.comf-donc1arkfhrdflearuinglactive.html

[10] C. Y. Qing, "Creating opportunities for students in active learning: lessons learnt from an electronic design contest" in Proc. 2nd International Conf. on Education Technology and Computer (ICETC), 2010.

[11] R. E. Ferdig, "Assessing technologies for teaching and learning: understanding the importance of technological pedagogical content knowledge," British Journal of Educational Technology, vol. 37, no. 5, pp. 749-760, 2006.

[12] C. E. Monteleoni, "Learning with online constraints: shifting concepts and active learning," Computer Science and Artificial Intelligence Laboratory Technical Report, 2006.

[13] S. Cottrell, The Study Skills Handbook, 2nd ed. New York: Palgrave MacMillan, 2003.

[14] S. Vonderwell and J. Savery, "Online learning: student role and reasiness," The Turkish Online Journal of Educational Technology, vol. 3, no. 3, May 2002.

[15] O. Talib, W. S. Luan, S. C. Azhar, and N. Abdullah, "Uncovering Malaysian students' motivation to learning science," European Journal of Social Sciences, vol. 8, no. 2, 2009.
[16] D. Austin and N. D. Mescia, Strategies to Incorporate Active Learning into Online Teaching, School of Library and Information Science, University of South Florida, Unpublished.

[17] M. G. Moore and G. Kearsley, Distance education: A systems view, Belmont, CA: Wadsworth Publishing Company, 1996.

[18] K. Mantyla, Interactive Distance Learning Exercises the Really Work! Alexandria, VA: American Society for Training and Development, 1999.

[19] A. S. Nurbiha, B. A. Mohamad, and T. Zaidatun, "Thermocollaborate: CSCL website for leaning thermochemistry," in Proc. International Technology, Education and Development Conf., Valencia, Spain, March 2010

[20] A. H. N. Dayana, B. A. Mohamad, J. Juhazren, and Y. Noraffandy, "Learning Acids and Bases through inquiry based website," in Proc. IEEE Conf. on Open Systems, ICOS, Kuala Lumpur, December 2010.

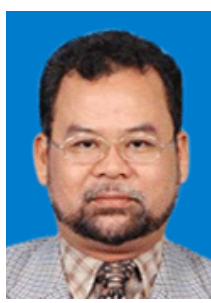

Mohamad Bilal Ali was born in Kuala Terengganu, Malaysia. He holds a master in Mathematics from Ohio Universiti, Athens, $\mathrm{OH}$, USA, he also obtained his Ph.D. in Educational Technology in 2009 from Universiti Teknologi Malaysia (UTM). His research interests include the use of interactive multimedia, e-learning and personalized learning. Currently, he works for the Department of Educational Multimedia and also as a dean in Faculty of Education UTM.

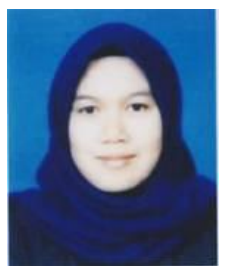

Noor Dayana Abd Halim is currently furthering her $\mathrm{Ph} . \mathrm{D}$. in Educational Technology field at Universiti Teknologi Malaysia (UTM). She is also working at UTM as a tutor. She obtained her first degree from UTM in Computer and Science with Education (Chemistry) in 2009. Her research interests include personalized learning environment (PLE), cognitive styles and human computer interactions.

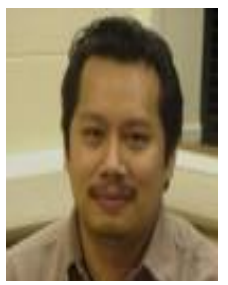

Nurbiha A. Shukor is a head of department at Department of Educational Multimedia, faculty of Education, Universiti Teknologi Malaysia. He is also a senior lecturer in multimedia education at the same department. He gained his Ph.D. in Computer Based Learning from University of Leeds in 2008 and Master of Education (Educational Technology) from Universiti Teknologi Malaysia. His research interests are in the area of designing learning objects for teaching and learning, e-learning, web technology and instructional design. 